\title{
Experimental Studies of Topographically Induced Atmospheric Turbulence near the Miyakejima Airport
}

\author{
by \\ Tokunosuke Fujitani, Tatsuo Hanafusa and Hiroshi Nishiyama \\ Meteorological Research Institute, Japan
}

\begin{abstract}
Atmospheric turbulence caused by the topographical features near an airport is one of the most important factors to be considered in aircraft operation. For, in Japan, many local airports are located in a topographically complicated area. In view of this, we made field observation of topographical turbulence near the Miyakejima Airport, which is located in the lee of a mountain in the winter monsoon season.

From the analysis of surface and airborne observations, it was found that topographical turbulence was predominant up to half of the mountain height and decayed in the leeward direction, but extended in the upward direction. The vertical distribution of the dissipation rate of turbulent kinetic energy was estimated from the values of vertical acceleration of the airplane. The vertical distribution of eddy viscosity was also estimated.
\end{abstract}

\section{Introduction}

Atmospheric turbulences, such as turbulence in the vicinity of cumulonimbus clouds, clear air turbulence (CAT), turbulence caused by topographical features (hereafter to be called topographical turbulence) and aircraft wake turbulence, are part of the atmospheric environment in which aircraft operate, and hence require serious consideration in aircraft operation for passenger safety and comfort as well as for economic and mission performance. Especially, topographical turbulence caused by the local topography near an airport has decisive effects on aircraft in the course of takeoff and landing. In Japan many local airports are located in a topographically complicated area, where topographical turbulence occurs frequently on the approaching flight path. It is considerably important to clarify the characteristics of topographical turbulence for aviation meteorology. However, only a few observational studies have been made to date (Cook et al., 1977). In recent years as part of the research project on an integrated airborne instrument display system, the development of a detection system of atmospheric turbulence has also been attempted. For these purposes field observation and wind tunnel model experiment on topographical turbulence near the Miyakejima Airport (RJTQ), the Izu Islands near the main land of Japan, were carried out and some results were obtained. In the present paper the results of airborne observation are mainly described and discussed. The characteristics of the mean wind field around Miyakejima Island estimated from long time field observation and wind tunnel experiment will be published in another paper.

\section{Topographical features of the Miyake- jima Airport}

The Miyakejima Airport is located on the southeast coast of the island and lies in the lee of Mt. Oyama in the winter monsoon season. Mt. Oyama in the central part of the island is $815 \mathrm{~m}$ (2674 feet) in height and has 
a conical shape as seen in Fig. 1. The frequency wind rose observed at the Miyakejima Meteorological Observatory located on the north side of the island shows that the prevailing wind direction in the winter season is west to northwest and hence the airport runway (oriented $20^{\circ}$ to $200^{\circ}, 1100 \mathrm{~m}$ in length, $30 \mathrm{~m}$ in width and $19.5 \mathrm{~m}$ (64 feet) above the sea surface) would be seriously influenced by topographical turbulence caused by that mountain. In the worst case about $60 \%$ of regular flight service in a month is interrupted by wind conditions. In the operations manual, the maximum cross-wind for safety landing is determined to be $15 \mathrm{~m} / \mathrm{sec}$ in case of the wind direction being from $260^{\circ}$ to $340^{\circ}$.

\section{Data collection and instrumentation}

In order to clarify the characteristics of topographical turbulence near the Miyakejima Airport, many kinds of field observation, both surface and airborne, were carried out around the airport in February 1977 for about five days, in which period the wind direction was west to northwest and the wind speed was about $15 \mathrm{~m} / \mathrm{sec}$ at a height of $1000-1500 \mathrm{~m}$. This condition was most suitable for the present observation and the data obtained were very useful for our analysis.

\subsection{Surface observation}

The three components of wind velocity were measured with a sonic anemometer (Kaijo Denki, PAT-311-1). This instrument, widely used now, measures both fluctuations and mean velocity. The wind antenna of the anemometer was installed on the top of the tower $6 \mathrm{~m}$ high near the runway. Observation was made during the daytime and three components of wind velocity were recorded on magnetic tapes in FM analog form.

A wind profile in the lowest $2000 \mathrm{~m}$ layer was measured by double-theodolite pilot balloon observation. The tracking of the

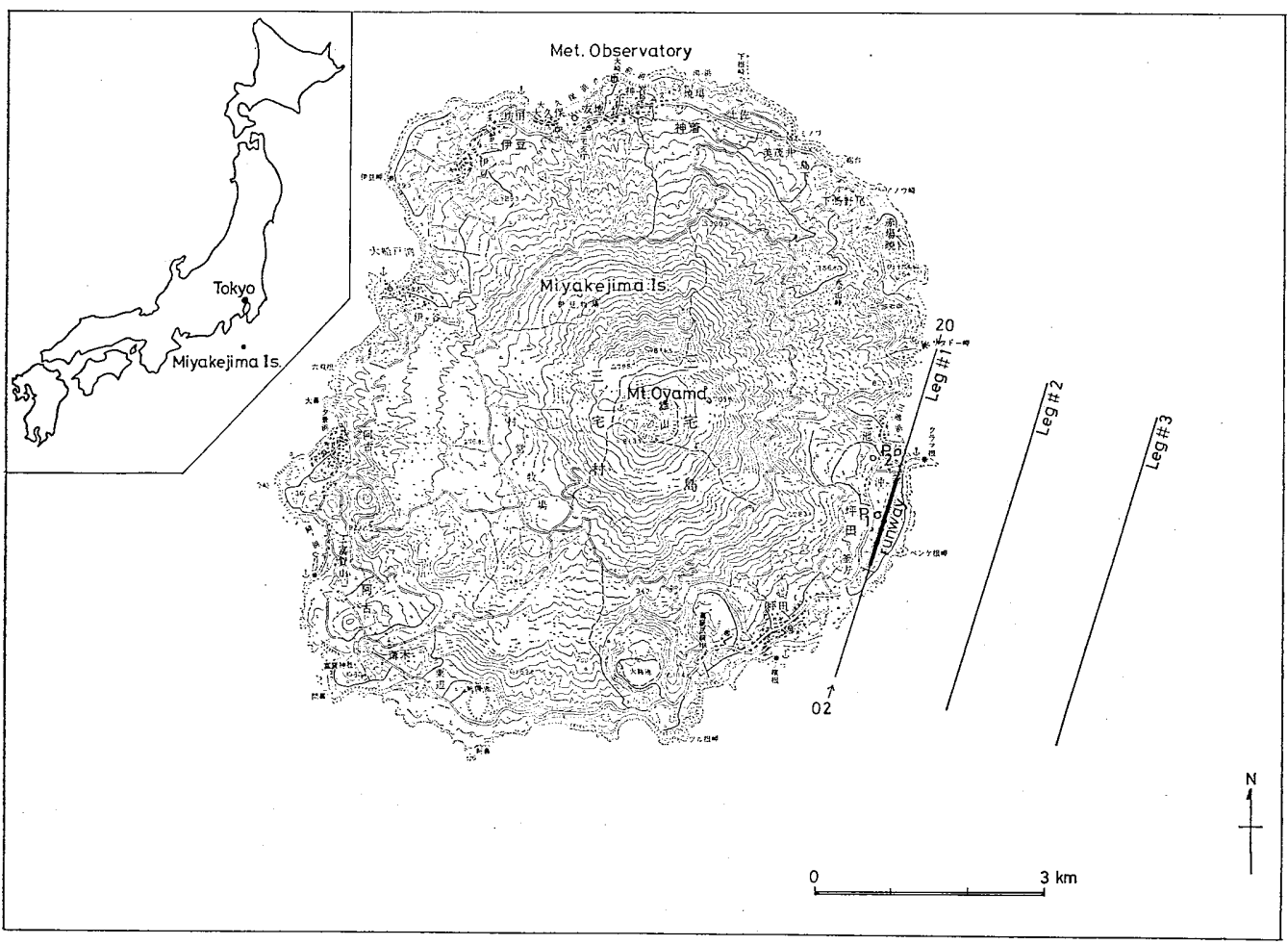

Fig. 1. Map of Miyakejima Island. 
balloon was done visually by the use of two digital theodolites placed at $\mathrm{P}_{1}$ and $\mathrm{P}_{2}$ about $1 \mathrm{~km}$ apart (see Fig. 1). The azimuth and elevation angles were recorded simultaneously at two points every 5 seconds in digital form. The balloon attained to a nominal ascent rate of $200 \mathrm{~m}$ a minute, and observation was made every hour during the daytime. Wind speed and direction were computed every 5 seconds and averaged over a 30 seconds period.

In addition to these observations temperature profile measurement with a lower troposphere radiosonde and the measurement of the wind field using a superpressure constant volume balloon (tetroon) were carried out.

\subsection{Airborne observation}

To clarify the three dimensional structures of topographical turbulence, the measurement of the vertical acceleration of an airplane induced by atmospheric turbulence was made near the Miyakejima Airport by the use of an airborne acceleration measuring system. The acceleration measuring system consists of a vertical gyro and two orthogonally mounted null-balance-type accelerometers set up on the gyro-stabilized gimbal. Therefore, it was possible to measure the airplane acceleration free from external influence of the pitch and roll motion of the airplane. Specifications of this system are summarized in Table 1. The observation airplane used in the present study is the anti-submarine patrol plane, P-2J of the 3rd Air Patrol Squadron
(Atsugi Base) of JMSDF (Japan Maritime Self Defence Force) and the essential specifications of this airplane are listed in Table 2. Observation was made along three flight legs, $\# 1$, $\# 2$ and $\sharp 3$, and these three legs were arranged at intervals of $1.5 \mathrm{~km}$ space as shown in Fig. 1. The flight leg $\# 1$ was along the runway and each leg was $4.5 \mathrm{~km}$ in length. Acceleration measurement was made at nine levels, 230, 400, 560, 730, 900, 1060, 1720, 2570 and 3370 feet above the sea surface and hence the lowest observational level on the runway was about 170 feet $(52 \mathrm{~m})$. The cruising speed of the airplane along, the legs was about $140-150 \mathrm{kt}$.

\section{Data analysis and results}

In the present paper the data collected in February 26 are analyzed and some of the results obtained are discussed.

\subsection{Analysis of surface observation}

The vertical wind profiles measured by pilot balloon observation are shown in Fig. 2 and the mean wind speed was averaged over 30 seconds as mentioned above. As is clear from this figure the mean wind speed exceeds $20 \mathrm{~m} / \mathrm{sec}$ above $200 \mathrm{~m}$ height, and in some cases exceeds 30 or $40 \mathrm{~m} / \mathrm{sec}$. The maximum value of wind speed appears at about $400-500$ $\mathrm{m}$ height. However, the wind speed at about $100 \mathrm{~m}$ height is about $10 \mathrm{~m} / \mathrm{sec}$ or so, and the mean wind speed for 30 minutes measured

Table 1. Specifications of acceleration measuring system.

\begin{tabular}{cc}
\hline Vertical gyro (VG-82 M, Tokyo Aircraft Instrument Co.) \\
\hline Gyro wheel & Induction motor driven (21000 rpm) \\
Self leveling & Gimbal mounted direct drive torquer \\
Pick-off & Pancake-type synchros \\
Measuring range & Pitch angle: $\pm 20^{\circ}$ \\
& Roll angle: $\pm 30^{\circ}$ \\
Frequency response & $\sim 5 \mathrm{~Hz}$ \\
\hline Accelerometer (4303, Systron Donner Co.) \\
\hline Type & Null-balance-type \\
Measuring range & $\pm 3 \mathrm{G}$ \\
Natural frequency & $60-150 \mathrm{~Hz}$ \\
Weight of pick-up & $18 \mathrm{gr}$ \\
\hline
\end{tabular}


Table 2. Specifications of $\mathrm{P}-2 \mathrm{~J}$.

\begin{tabular}{ll}
\hline Type & Anti-submarine patrol plane \\
\hline Over-all width & $101 \mathrm{ft} .31 / 2$ inch $(30.87 \mathrm{~m})$ \\
\hline Over-all length & $95 \mathrm{ft} .103 / 4$ inch $(29.23 \mathrm{~m})$ \\
\hline Over-all height & $29 \mathrm{ft} .31 / 2$ inch $(8.93 \mathrm{~m})$ \\
\hline Empty weight & $425001 \mathrm{~b} .(19 \mathrm{ton})$ \\
\hline Maximum take-off weight & $72900 \mathrm{lb} .(33 \mathrm{ton})$ \\
\hline Engine & Turboprop engine $\times 2$ \\
& Turbojet engine $\times 2$ \\
\hline Speed & Cruising speed : $200 \mathrm{kt}$ \\
& Maximum speed : $350 \mathrm{kt}$ \\
& Minimum control speed : $100 \mathrm{kt}$ \\
\hline Limiting acceleration & $3.0 \mathrm{G}$ (in still air) \\
& $1.8 \mathrm{G}$ (in turbulence) \\
\hline
\end{tabular}

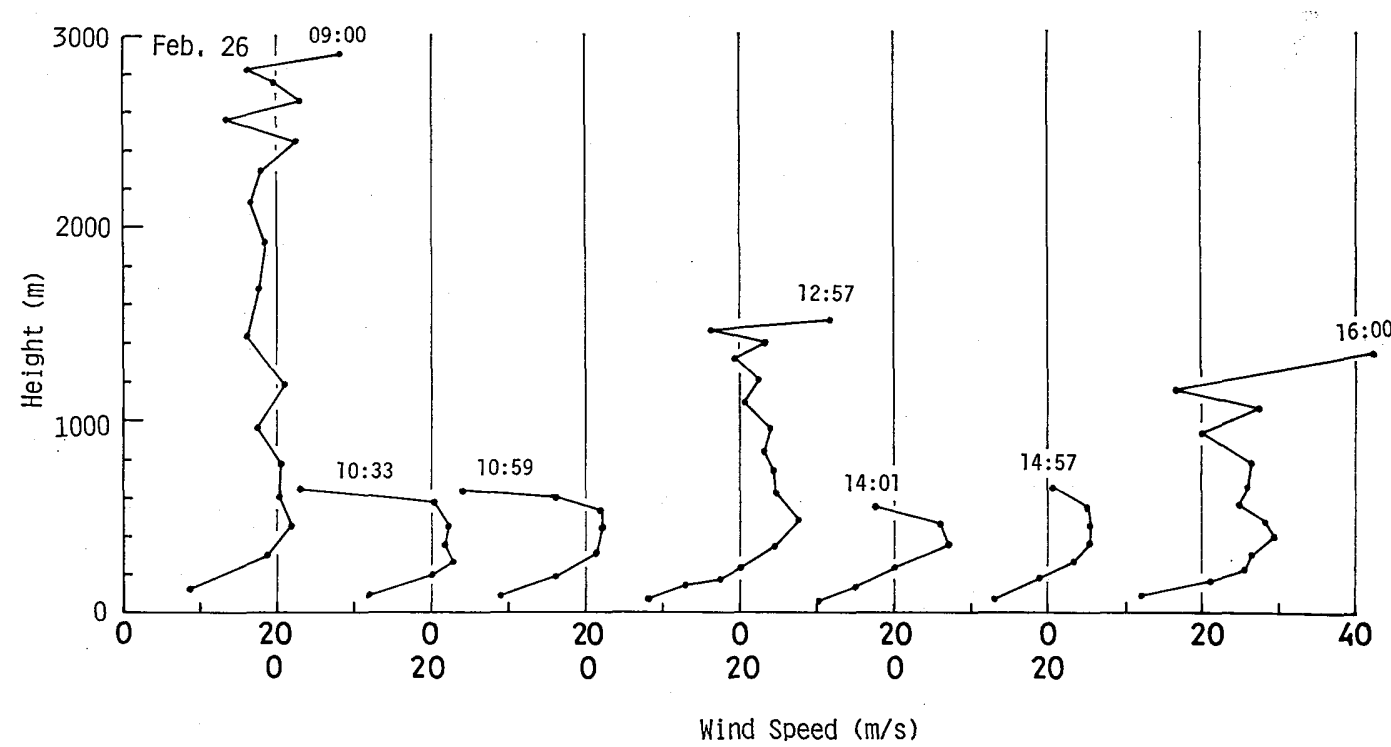

Fig. 2. Mean wind profiles measured by pilot balloon observation.

by the sonic anemometer at $6 \mathrm{~m}$ height near the runway is about $5 \mathrm{~m} / \mathrm{sec}$ as shown in Table 3. This fact indicates that a strong wind exists at a height of a few hundred meters, that is, halfway up height of the mountain. In this observational period the wind direction was almost west in the whole layer. The vertical wind shear estimated from these 7 runs of pibal observation in the lowest $600 \mathrm{~m}$ layer is plotted in Fig. 3. According to the interim criteria for reporting on vertical wind shear (Recommendation of $\mathrm{ICAO}$ ), the intensity of vertical wind shear in this figure corresponds to 'moderate' wind shear. As shown in this figure the vertical wind shear decreases almost linearly with height and the empirical relation obtained from these data using the least squares method is shown as a solid line in this figure and can be expressed as follows:

$$
z=-4.572 \times 10^{3}\left(\frac{\partial V}{\partial z}\right)+448.6
$$

where $z$ (unit: $\mathrm{m}$ ) is the height above the runway and $\partial V / \partial z$ (unit: $\sec ^{-1}$ ) the vertical wind shear. 
Table 3. Mean wind speed and related statistical parameters measured by the sonic anemometer.

\begin{tabular}{lccccccccc}
\hline $\begin{array}{c}\text { Feb. } 26, \\
{ }_{77}\end{array}$ & $\begin{array}{r}08: 30- \\
09: 00\end{array}$ & $\begin{array}{r}09: 00- \\
09: 30\end{array}$ & $\begin{array}{r}09: 30- \\
10: 00\end{array}$ & $\begin{array}{r}10: 00- \\
10: 30\end{array}$ & $\begin{array}{r}10: 30- \\
11: 00\end{array}$ & $\begin{array}{r}11: 20- \\
11: 50\end{array}$ & $\begin{array}{r}11: 50- \\
12: 20\end{array}$ & $\begin{array}{r}12: 20- \\
12: 50\end{array}$ & $\begin{array}{r}12: 50- \\
13: 20\end{array}$ \\
\hline$\overline{\mathrm{U}}(\mathrm{cm} / \mathrm{s})$ & 508 & 462 & 535 & 519 & 525 & 514 & 494 & 485 & 491 \\
$\sigma_{u}(\mathrm{~cm} / \mathrm{s})$ & 213 & 183 & 210 & 209 & 211 & 228 & 223 & 218 & 196 \\
$\sigma_{w}(\mathrm{~cm} / \mathrm{s})$ & 187 & 133 & 153 & 153 & 153 & 156 & 165 & 154 & 160 \\
$\sigma_{u} / \overline{\mathrm{U}}$ & 0.42 & 0.40 & 0.39 & 0.40 & 0.40 & 0.44 & 0.45 & 0.45 & 0.40 \\
$\sigma_{u} / \sigma_{w}$ & 1.14 & 1.38 & 1.37 & 1.37 & 1.38 & 1.46 & 1.35 & 1.42 & 1.23 \\
\hline
\end{tabular}

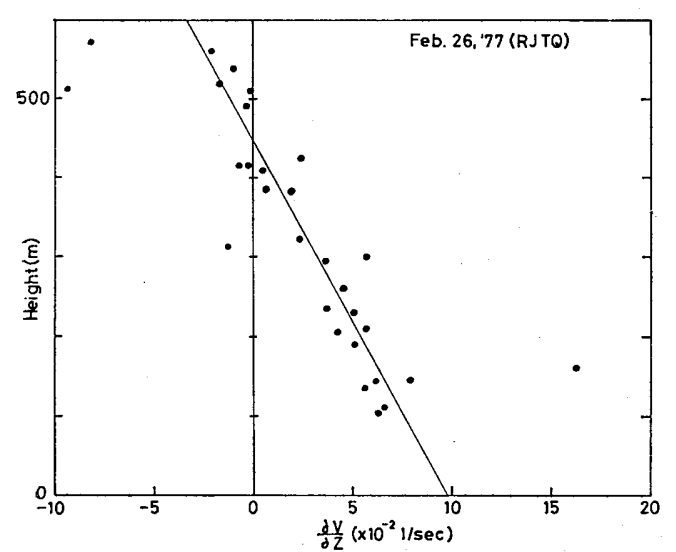

Fig. 3. Vertical distribution of wind shear.

The three components of velocity fluctuations measured by the sonic anemometer were digitized at $5 \mathrm{~Hz}$ using $\mathrm{A} / \mathrm{D}$ converter, and statistical parameters and the spectra of wind fluctuations were obtained. The statistical parameters on February 26 are tabulated in Table 3. As is evident in this table the values of mean wind speed for 30 minutes are about $5 \mathrm{~m} / \mathrm{sec}$, remarkably smaller than those obtained by pilot balloon observation as previously described in Fig. 2. However, the values of intensity of turbulence, $\sigma_{u} / \overline{\mathrm{U}}$, are very large, three or four times larger than those obtained over the flat land surface. These values are the same as those obtained over an urban area (Nakano et al., 1974). The ratio of r.m.s. values of horizontal and vertical wind fluctuations are 1.1-1.5, which are smaller than 2.0 obtained over the flat land surface (e. g. Lumley and Panofsky, 1964). It is clearly seen from this table that the vertical wind fluctuations caused by topo- graphical features are somewhat larger than those over the flat land surface. The spectra of horizontal and vertical wind fluctuations are shown in Figs. 4(a) and 4(b). These spectra were computed from the data of 12 successive runs, each for 10 minutes, and the spectral densities obtained were smoothed by the eye. The abscissa of these figures is radian wave number $(\mathrm{rad} / \mathrm{cm})$ converted from frequency by using Taylor's frozen turbulence hypothesis. As is evident from these figures the spectra obey the wellknown $-5 / 3$ power law in the ine rtial subrange in the region of radian wave number of $10^{-2}$. The spectra can be expressed as follows with usual nomenclatures :

$$
F(k)=\alpha \varepsilon^{2 / 3} k^{-5 / 3}
$$

Using this formula the dissipation rate of turbulent kinetic energy, $\varepsilon$, can be estimated from spectral density in the inertial subrange. In order to estimate the dissipation rate it is necessary to use Kolmogorov constant, $\alpha$, which is not yet completely determined. In the present analysis the value 0.55, which was obtained by Paquin and Pond (1971) for the horizontal component, was used. Based on the theory of isotropic turbulence the value for the vertical component is 0.73 . Estimated $\varepsilon$ is $2.2 \times 10^{3} \mathrm{~cm}^{2} \mathrm{sec}^{-3}$ for the horizontal component and $2.4 \times 10^{3} \mathrm{~cm}^{2} \mathrm{sec}^{-3}$ for the vertical, and hence the averaged value is about $2.3 \times 10^{3} \mathrm{~cm}^{2} \mathrm{sec}^{-3}$. This value is about ten times larger than that obtained over the land surface and almost the same as that over the forest (Taylor, 1972). This fact indicates that the mechanical turbulence caused by topographical features was extreme- 
ly predominant near the runway.

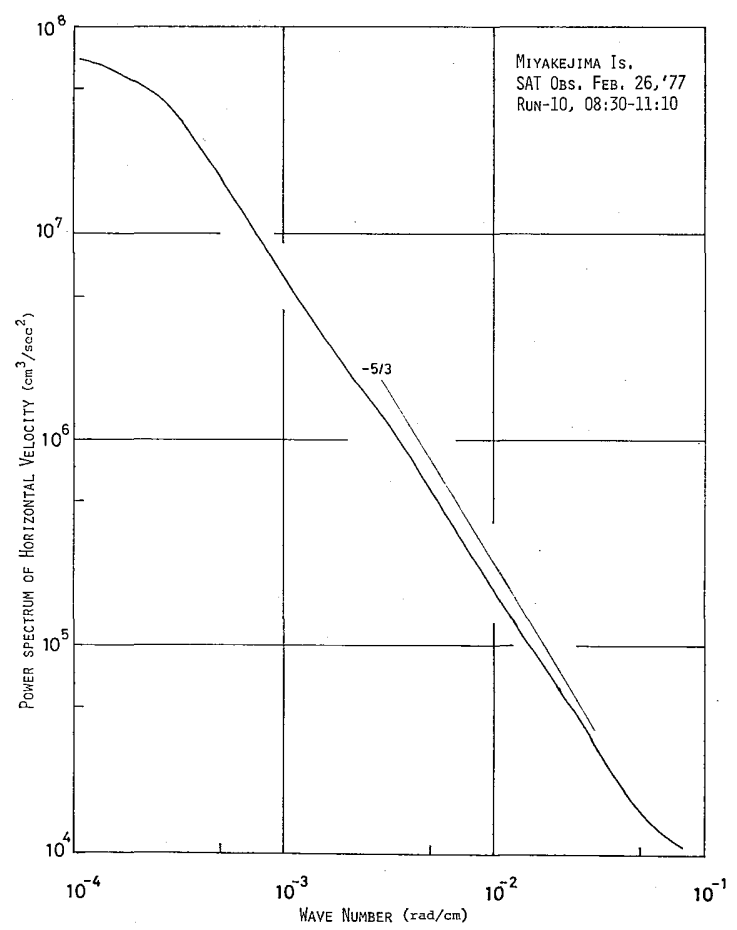

Fig. 4(a). Spectrum of horizontal wind fluctuations.

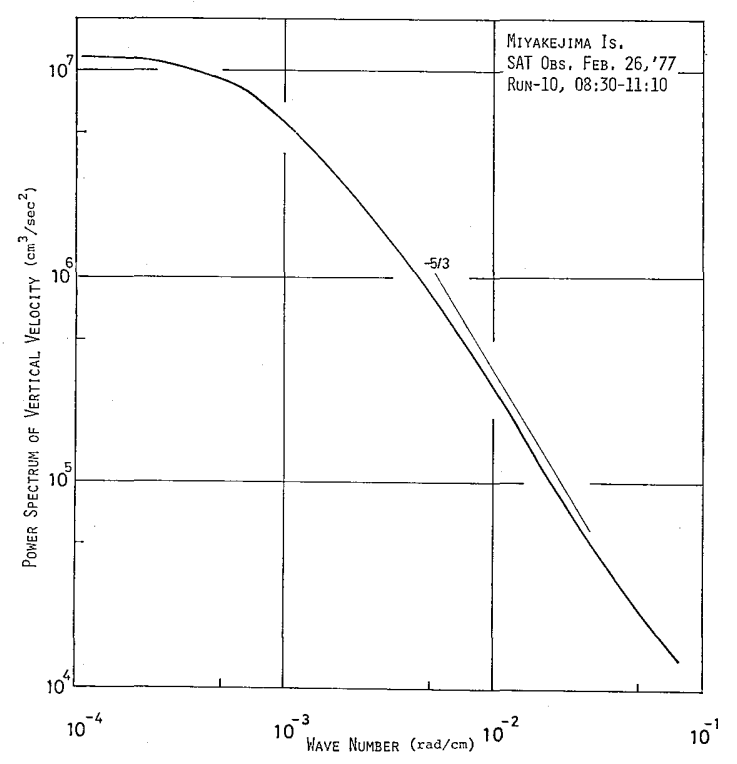

Fig. 4(b). Spectrum of vertical wind fluctuations.

\subsection{Analysis of airborne observation}

Time series plots of the vertical accelration of the airplane are shown in Fig. 5. These data were obtained at various observational heights and legs. To reduce the superposed high frequency noise induced by airplane engine vibration and rotation of the gyro-wheel, the low-pass filtering technique with a cut-off frequency of $10 \mathrm{~Hz}$ was adopted for data reproducing procedure. This figure shows that, at higher observational levels, only the slow time variation of acceleration appears on the records. These low frequency fluctuations might be caused artificially by the pilot's flight control. However, at lower levels, especially below about 1000 feet, high frequency fluctuatins of vertical acceleration are predominant throughout the legs. Above 1000 feet it seems that the intensity of vertical acceleration increases as one goes further away from the island, that is, the acceleration along the leg $\# 3$ is larger than that along the leg $\# 1$, but below 1000 feet the acceleration along the leg $\# 1$ is larger than those along the legs $\# 2$ and $\# 3$. As is evident from this figure topographical turbulence was predominant in the area below half of the height of the Mt. Oyama and was uniform in the vertical direction as one goes further away from the runway. In this figure the peak to peak value of vertical acceleration frequently exceeds 1 $\mathrm{G}$, which is extremely large for this airplane, since the limiting acceleration of $\mathrm{P}-2 \mathrm{~J}$ in turbulence is settled to be $1.8 \mathrm{G}$ as shown in Table 2. According to the ICAO Standard, the topographical turbulence caused by $\mathrm{Mt}$. Oyama is 'moderate' or 'severe' turbulence. The vertical distribution of the peak values of upward and downward acceleration is shown in Fig. 6. The characteristics of distribution mentioned above are well expressed in this figure. For quantitative analysis the acceleration data were converted to digital form at $20 \mathrm{~Hz}$ using $\mathrm{A} / \mathrm{D}$ converter, and before digitizing to reduce the high frequency noise mentioned above, the band-pass filtering technique with cut-off frequencies of 0.5 and 


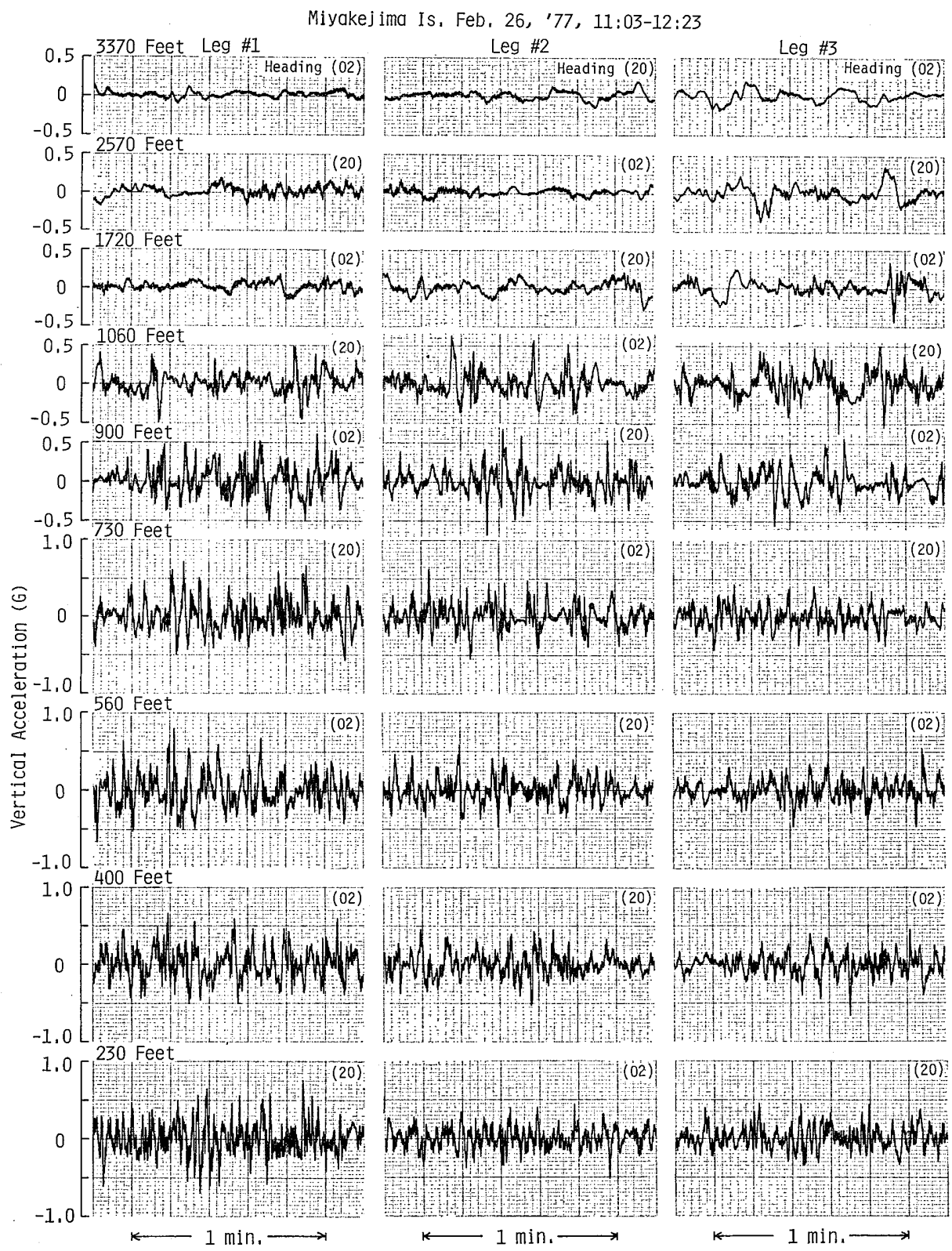

Fig. 5. Time series plots of vertical accelerations of the airplane (scaling unit of ordinate is gravitational acceleration).

$5.0 \mathrm{~Hz}$ was abopted in the data reproducing procedure. These cut-off frequencies are equivalent to the wave length of 14 and 140 $\mathrm{m}$, and hence the shorter limit of the wave length is half of the over-all length of this airplane and the longer limit is about four times longer than the over-all length. There- fore, it would be considered that the range of wave length includes the whole atmospheric turbulence influencing this airplane. In Fig. 7 the vertical profiles of peak values of acceleration estimated from these bandpass filtered data are shown. A tendency similar to that found in Fig. 6 can be seen in this 

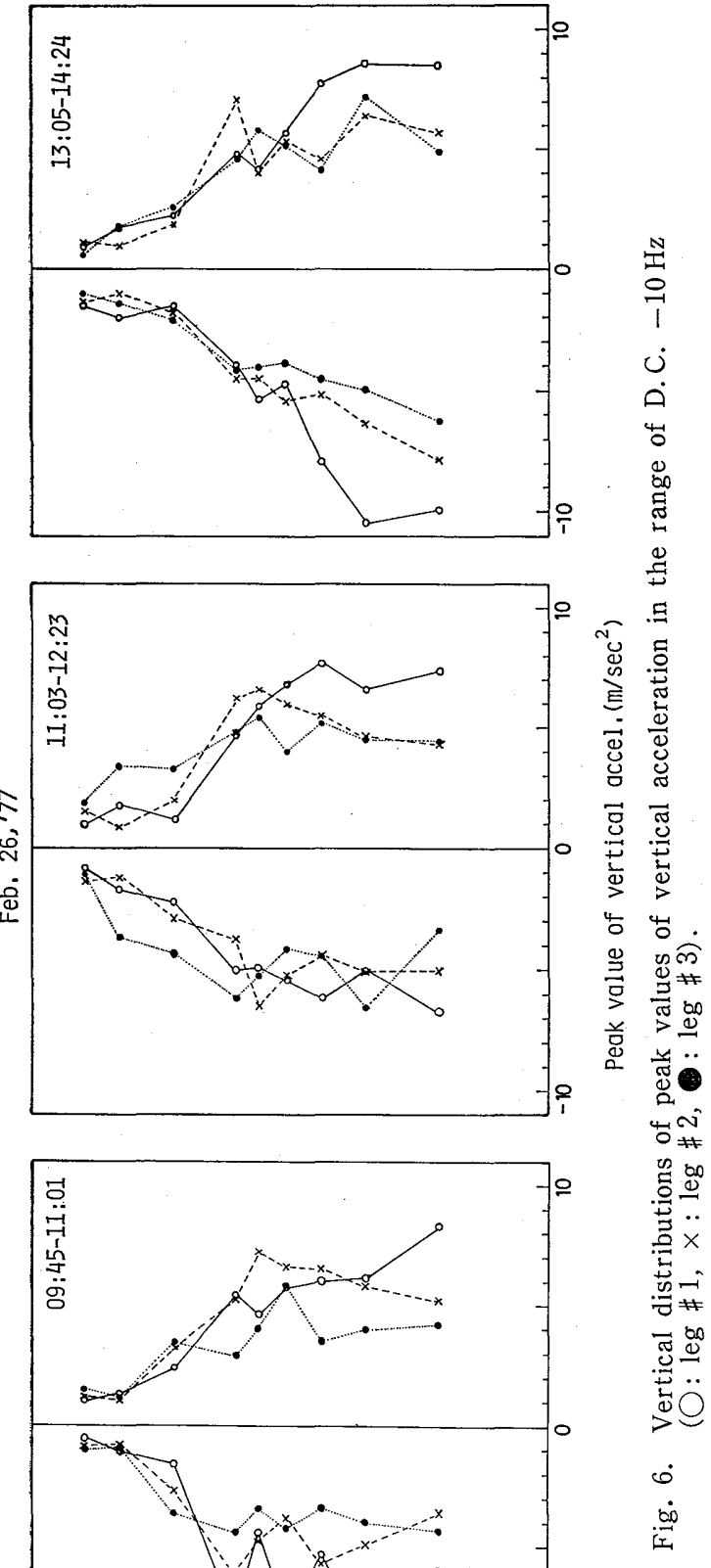

figure. From these figures it could be considered that topographical turbulence is predominant below about 1000 feet, half of the mountain height, and spreads in the leeward direction. The vertical distributions of r. m.s. values of vertical acceleration along the observational legs are shown in Fig. 8, from which it is evident that the r.m.s. values change remarkably at about 1000 feet. As implied in this figure the r.m.s. values below 1000 feet along the legs $\sharp 2$ and $\# 3$ do not change with height very much, but the values along the leg $\# 1$ increase gradually with decreasing height. Furthermore, there is the general tendency that the r.m.s. values along the leg $\# 1$ are larger than those along the legs \#2 and \#3 below about 1000 feet, but above about 1000 feet the opposite tendency can be seen. These results suggest that topographical turbulence decays in the leeward direction, but spreads in the upward direction. The spectra of vertical acceleration at various observational levels along the leg $\# 1$ are shown in Fig. 9. It is clear from this figure that the spectra obtained have a similar shape at all observational levels, but the spectra estimated from the data above the height of about 1000 feet have small spectral density. This fact implies that the airplane responds to topographical turbulence in almost the same manner at all observational levels. The spectral peak that appears at about 2.5 $\mathrm{Hz}$ might correspond to the fundamental mode of main wing vibration. An important turbulence factor is the r.m.s. value of vertical acceleration loads (gust loads) which are imposed on the airplane. $\sigma_{g}$, which is r.m.s. value of the vertical acceleration, can be expressed as follows:

$$
\sigma_{g}^{2}=\int_{0}^{\infty}\left[A^{2}(f) F(f)\right] d f
$$

where $A(f)$ is the amplitude response factor relating the airplane's vertical accelerations to the vertical air velocity and $F(f)$ the spectral function of vertical air velocity. It fortunately turns out that the inertial subrange includes those gusts which are of primary importance to many airplane gust loads and 


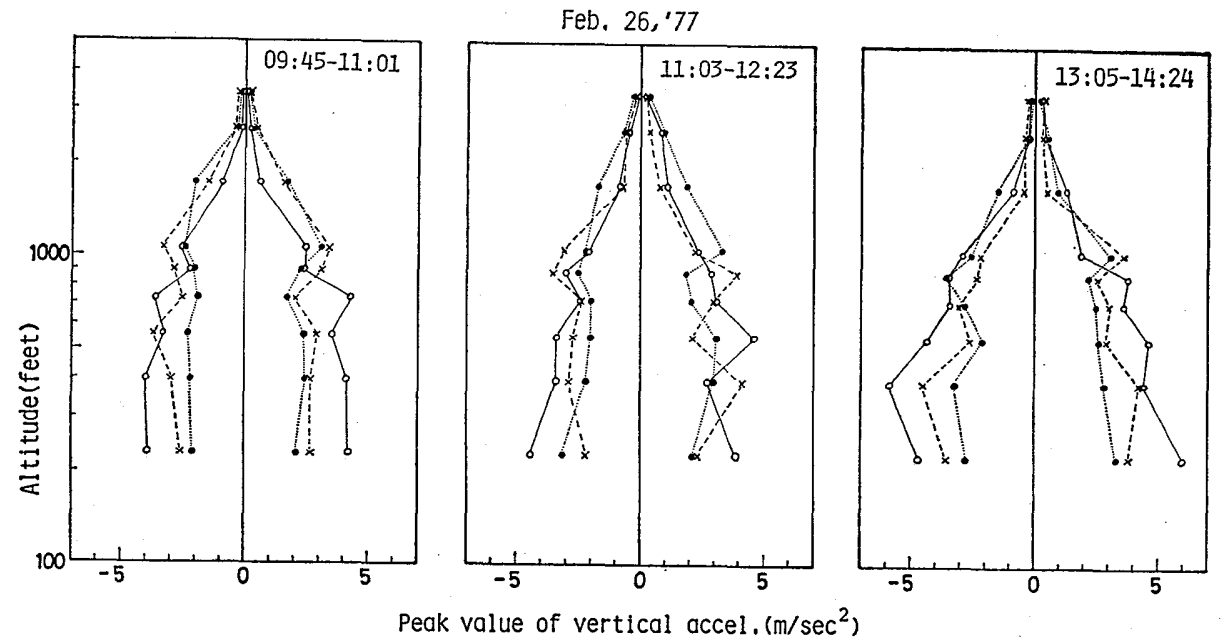

Fig. 7. As in Fig. 6, but for the range of $0.5-5 \mathrm{~Hz}$.

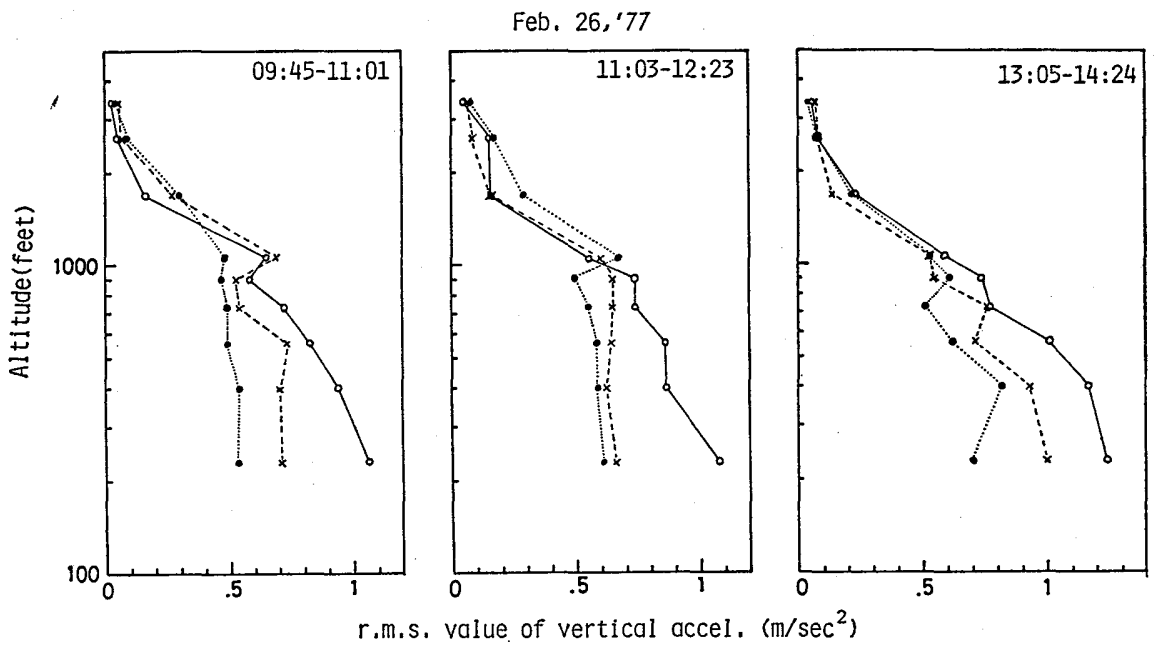

Fig. 8. Vertical distributions of r.m.s. values of vertical acceleration $(\bigcirc$ : leg $\# 1, \times$ : leg $\# 2$, : leg $\# 3$ ).

the gust loads for the slow airplane come from eddies entirely within the inertial subrange, that is, $A(f)$ would be negligibly small outside of the inertial subrange (MacCready, 1964). This is generally valid except for the very fast airplane. In the inertial subrange $F(f)$ can be expressed as Equation (2), therefore Equation (3) becomes

$$
\sigma_{g}=K \varepsilon^{1 / 3}
$$

Thus the r.m.s. value of vertical acceleration is proportional to $\varepsilon^{1 / 3}$. $K$ is a function of the airplane response characteristic, and then varies somewhat with altitude, airplane weight and speed as well as airplane type. $K$ increases with higher air speed. If $K$ is determined experimentally it is possible to estimate the dissipation rate of turbulent kinetic energy, $\varepsilon$, using above Equation (4). The dissipation rate is an important index to atmospheric turbulence, and helps to estimate the characteristics of turbulence. In the present analysis the proportional constant $K$ was determined by the method described 


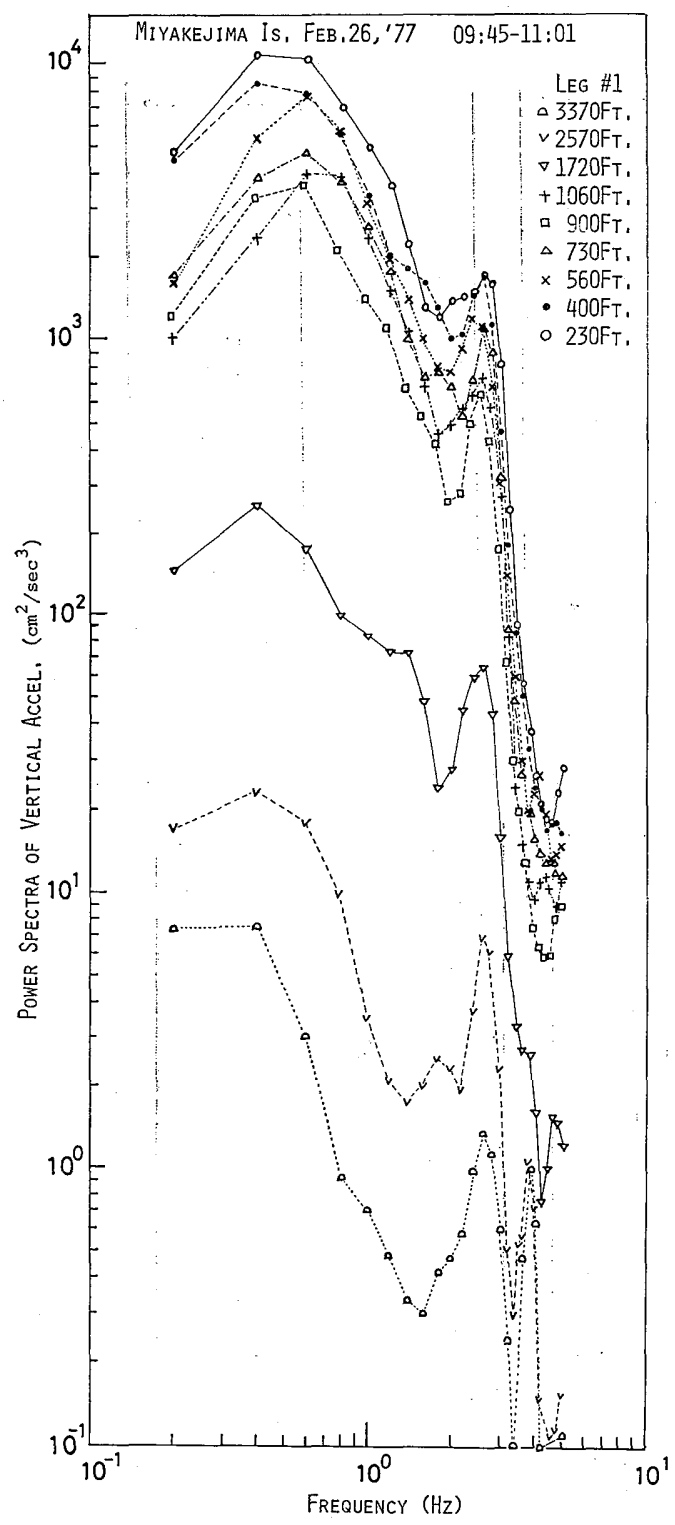

Fig. 9. Spectra of vertical accelerations of the airplane.

below. As previously mentioned, the average value of the dissipation rate was obtained from the wind fluctuation observation at a height of $6 \mathrm{~m}$ near the runway. It is well known that the dissipation rate is inversely proportional to height in the atmospheric surface layer. Therefore, the value of the dissipation rate at a height of $50 \mathrm{~m}$ above the runway, that is, the lowest observational height of the airplane, can be estimated by making use of this relation. At this level the r.m. s. value of vertical acceleration of the airplane was obtained from airborne observation: If we compare the estimated dissipation rate with the observed r.m.s. value, it is possible to determine the proportional constant $K$. The estimated value of $K$ is 16.4 in the present analysis. Using this proportional constant $K$ and measured r.m.s. values of vertical acceleration it is possible to estimate the dissipation rate in the upper layer. The estimated values of the dissipation rate are plotted in Fig. 10. As is evident from this figure the values of the dissipation rate along the leg $\$ 1$ increase rapidly with decreasing height below about 1000 feet, but those along the legs $\# 2$ and $\# 3$ change gradually with height. On the other hand, the values of the dissipation rate above about 1000 feet are negligibly small. These estimated values agree approximately with the turbulence magnitude scale suggested by MacCready (1964). In order to compare this result with other observational results, the average values of these 3 runs along the leg $\# 1$ were computed and shown in Fig. 11 . The dissipation rate over densely timbered country was obtained from the airplane observation data by Taylor (1972) and the values over the flat land surface were measured by tethered balloon observation (Rayment, 1973). These data are plotted in the same figure to be compared with the present results. The vertical profile of the present observation is somewhat similar to those of other results. The values in the lower layer are almost the same as those obtained over the rough surface, while the values in the upper layer are almost the same as those over the flat surface. This fact implies that mechanical turbulence was predominant in the lower layer as mentioned above. In Fig. 12 the average values of the dissipation rate along the leg $\# 1$ are also shown on a log-linear scale. This figure clearly shows that below about $300 \mathrm{~m}$ (about 1000 feet) the relation can be expressed by the following simple experimental equation: 

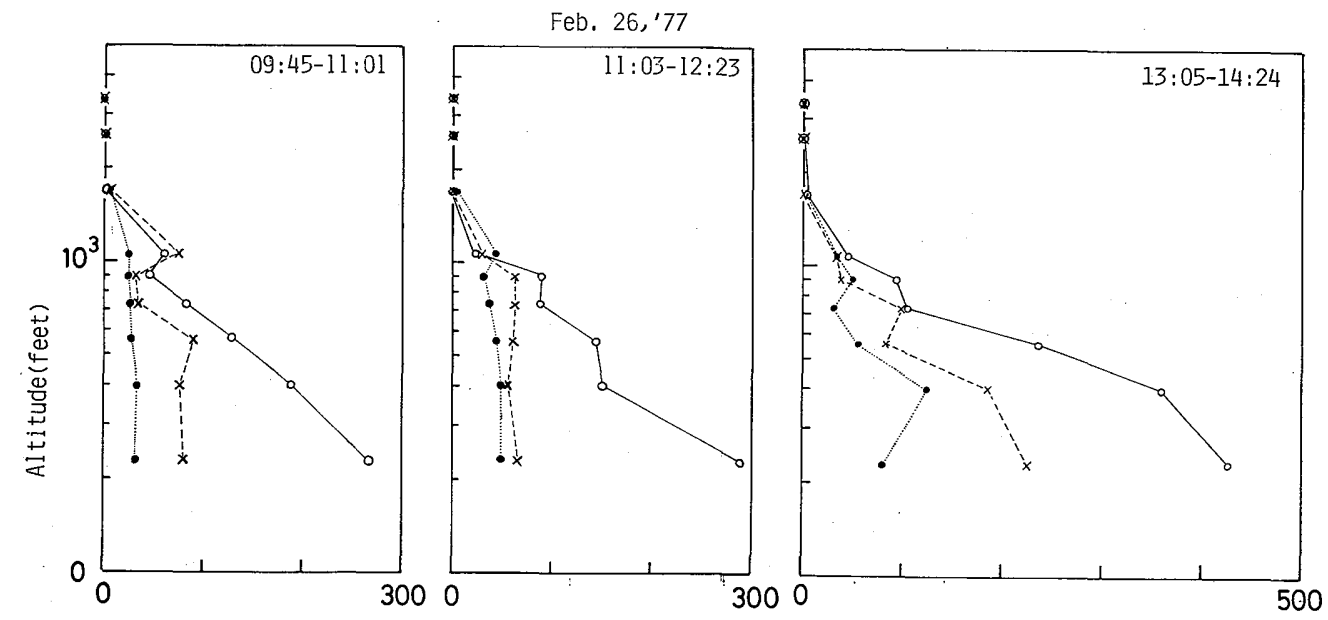

$\epsilon:$ Dissipation of turbulent kinetic energy $\left(\mathrm{cm}^{2} / \mathrm{s}^{3}\right)$

Fig. 10. Vertical distributions of estimated $\varepsilon(\bigcirc: \operatorname{leg} \# 1, \times: \operatorname{leg} \# 2,0$ : leg \#3).

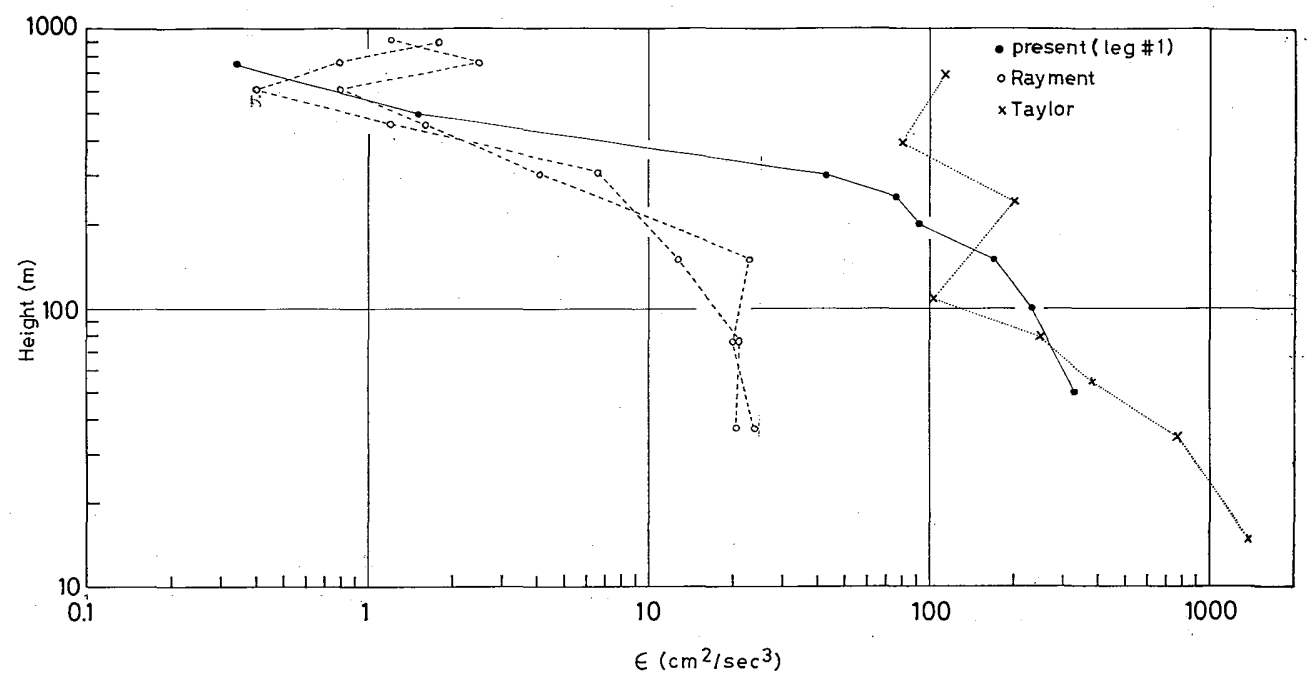

Fig. 11. Vertical profiles of $\varepsilon$.

$\log Z=-0.00264 \varepsilon+2.589$

where $Z$ (unit: $m$ ) is the height above the runway and $\varepsilon$ is expressed in c.g. s. unit.

In neutral conditions the dissipation rate of turbulent kinetic energy can be expressed in the following manner, assuming horizontally homogeneous turbulence and steady state conditions :

$$
\varepsilon=u_{*}^{2} \frac{\partial V}{\partial z}
$$

In the present observation the stratification condition was almost neutral and hence this relation might be applicable. As previously mentoned the vertical distribution of the dissipation rate and the wind shear can be expressed by Equations (1) and (5). Substituting these equations into Equation (6), $u_{*}{ }^{2}$, the covariance of horizontal and vertical wind fluctuations $\overline{-u^{\prime} w^{\prime}}$, can be estimated. The estimated vertical distribution of $\overline{-u^{\prime} w^{\prime}}$ is, shown in Fig. 13, where the covariance value obtained from the direct measurement 


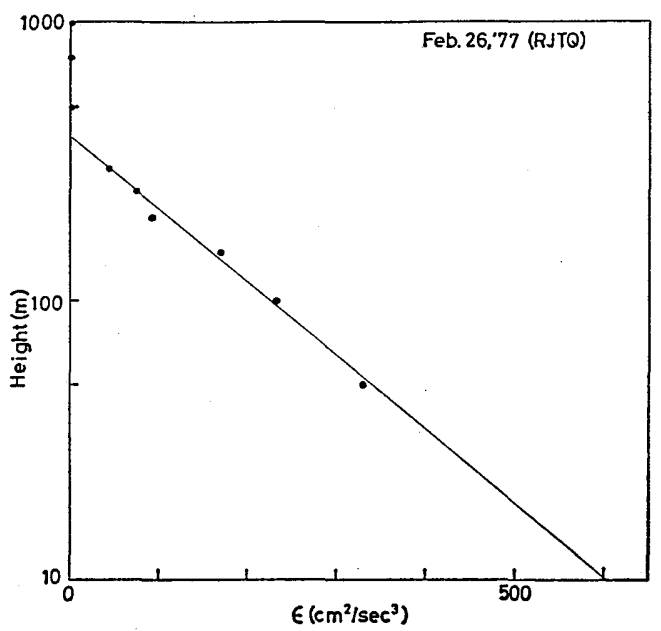

Fig. 12. Vertical profile of $\varepsilon$ along leg $\# 1$ on log-linear scale.

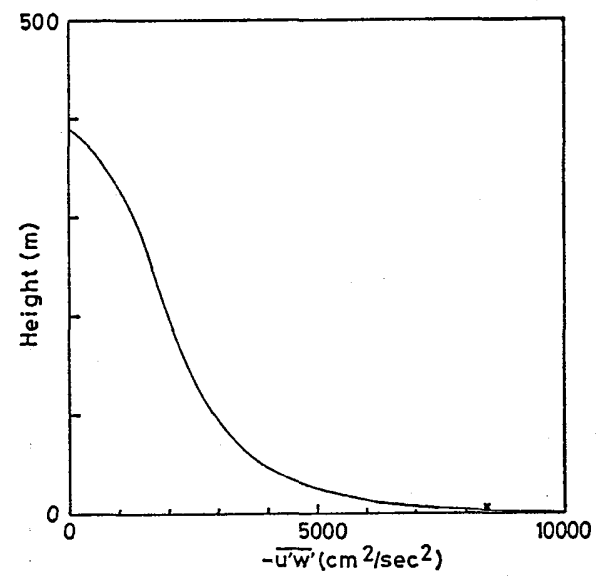

Fig. 13. Estimated vertical profile of $-\overline{u^{\prime} w^{\prime}}$.

of wind fluctuations by the sonic anemometer is also shown. This value was obtained from 16 successive runs each for 10 minutes and the difference between the observed and the estimated value is only about $14 \%$. The vertical distribution shows a similar shape to that generally obtained in the atmospheric boundary layer. The eddy viscosity $K_{m}$ can also be estimated from Equation (6) and the estimated vertical distribution is also shown in Fig. 14. The estimated value is about $10^{4}-10^{5} \mathrm{~cm}^{2} \mathrm{sec}^{-1}$, which is the same as that obtained experimentally in the atmospheric boundary layer. These facts imply that the

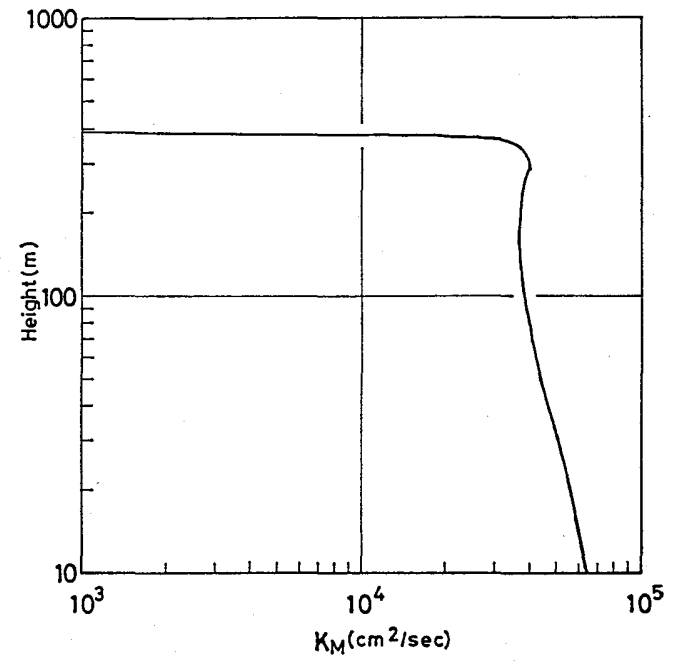

Fig. 14. Estimated vertical profile of eddy viscosity $K_{m}$.

estimated profile of the dissipation rate would be reasonable in the atmospheric boundary layer influenced by topographical turbulence.

From these results described above, we may conclude that this method of estimation of the dissipation rate is applicable to atmospheric turbulence detection.

\section{Concluding remarks}

To investigate the characteristics of topographical turbulence, surface and airborne observations were carried out successfully near the Miyakejima Airport in the winter monsoon season. The vertical wind shear obtained corresponded to 'moderate' wind shear and the vertical wind shear decreased linearly with height below $600 \mathrm{~m}$ height. Three components of wind fluctuations were measured by the sonic anemometer, and the statistical parameters and spectra of wind fluctuations were obtained. Using spectral density in the inertial subrange, the dissipation rate of turbulent kinetic energy was estimated. The r.m.s. value of vertical acceleration of the airplane was computed from the data obtained by the accelerometer up to about 3300 feet around the runway. By the use of these r.m.s. values the dissipation rate of turbulent kinetic energy was estimated. 
From these results it became evident that topographical turbulence was predominant up to halfway up the height of the mountain and spread over and decayed in the leeward direction, but turbulence extended in the upward direction. The values obtained of the dissipation rate in the lower layer were almost the same as those obtained over the rough surface and the values in the upper layer were the same as those obtained over the flat land surface. Relating the vertical distributions of the dissipation rate to the wind shear, which was determined experimentally, the vertical distribution of momentum flux was estimated by the use of the budget equation of turbulent kinetic energy. The estimated value agrees well with that obtained by direct measurement. The vertical distribution of eddy viscosity was also estimated and a value reasonable in the atmospheric boundary layer was obtained.

Acknowledgements:-The authors are indebted to Prof. K. Washizu of the University of Tokyo and Dr. S. Soma of Seikei University for their encouragement throughout this study and also express their appreciation to the 3rd Squadron of JMSDF for their cooperative work in airborne observation. This study was sponsored by the Japan Science and Technology Agency.

\section{References}

Cook, N.J., B.H. Coulson and W. Mckay, 1977: Wind conditions around the Rock of Gibraltar. J. Industrial Aerodynamics, 2, 289-309.

Lumley, J.L. and H.A. Panofsky, 1964: The structure of atmospheric turbulence. John-Wiley \& Sons, N.Y., pp. 131-156.

MacCready, P.B., Jr., 1964: Standardization of gustiness values from aircraft. J. Appl. Met., $3,439-449$.

Nakano, M., K. Takeuchi, Y. Mitsuta and T. Hanafusa, 1974: Structure of planetary boundary layer over urban area. Kishokenkyu Note, 119, 133-141 (in Japanese).

Paquin, J.E. and S. Pond, 1971: The determination of the Kolmogoroff constants for velocity, temperature and humidity fluctuations from second- and third-order structure functions. J. Fluid Mech., 50, 257-269.

Rayment, R., 1973: An observational study of the vertical profile of the high frequency fluctuations of the wind in the atmospheric boundary layer. Boundary Layer Met., 3, 284-300.

Taylor, R.J., 1972: Aircraft measurements of dissipation of turbulent kinetic energy. Quart. J. Roy. Met. Soc., 98, 658-661.

\title{
三宅島空港周辺の地形性乱気流の研究
}

\author{
藤谷徳之助・花房龍男 ·西山 宏 \\ 気象研究所
}

\begin{abstract}
空港周辺の局地的な地形によって生じる地形性乱気流は，これが航空機にとって最も影響の受けやすい離着陸時 に作用するという点，又，国内空港の多くが，地形性乱気流の発生しやすい複雑な地形の場所飞建設されていると いら点から，航空機の安全運航に最も大きな影響を及汸している。この地形性乱気流の性質を明らかにするために， 冬期季節風時飞孤峰の風下側飞位置する，伊豆諸島の三宅島空港を選しで，地上及び航空機観測を実施した。その 結果, 地形性乱気流は山の高さの半分以下の部分で卓越して招り，風下側に減衰しながら拡がっているが，上方に も及んでいることが明らかとなった。又，航空機の鉛直加速度の標準偏差から推定した乱れの粘性消散率の值は， 下層では森林上で得られた值に，又，上層では平坦地上で得られた値と同程度であることが判った。さらにこれら の值を用いて，運動量輸送量や渦粘性係数の鉛直分布についても推定がなされた。
\end{abstract}


The following parts,

(1) (Received December 17, 1980) and

(2) Meteorological Research Institute, Japan (Received December 17, 1980)

are missing on pages 19 and 37 in PAPERS IN METEOROLOGY

AND GEOPHYSICS Vol. 32 , No. 1.

Therefore would you please insert the parts under the Title, respectively. 